\title{
Purines as Amplifiers of the Antibiotic Activity of Phleomycin against Escherichia coli B
}

\author{
By ANNETTE M. ANGYAL AND G. W. GRIGG \\ C.S.I.R.O., Division of Animal Genetics, P.O. Box 90, Epping, \\ N.S.W. Australia, $2 \mathrm{I} 2 \mathrm{I}$ \\ AND R. J. BADGER, D. J. BROWN AND J. H. LISTER \\ Medical Chemistry Group, John Curtin School of Medical Research, \\ P.O. Box 334, Canberra City, Australia, 260 I \\ (Received 26 April 1974; revised 28 May 1974)
}

Phleomycin is a copper-containing compound isolated from Streptomyces verticillus (Maeda, Kosaka, Yagishita \& Umezawa, 1956; Takita et al. 1972) with a broad range of antibiotic and antitumour activity (Smale, Montgillion \& Pridham, I96r ; Bradner \& Pindell, 1962; Tanaka, Yamaguchi \& Umezawa, I963; Kihlman, Odmark \& Hartley, 1967; Iwata \& Consigli, I97I; Reiter, Milewskiy \& Kelley, 1972). At low concentrations it induces DNA

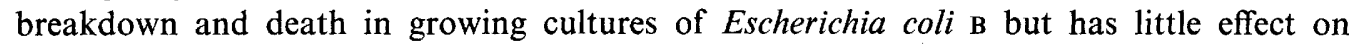
stationary-phase bacteria (Grigg, I969). At higher concentrations this difference disappears. Exposure of phleomycin-treated bacteria to caffeine, pyronin $Y$, coumarin or certain thiopurines initiates DNA degradation and death. The effects are similar to those caused by increasing the phleomycin concentration up to roo-fold (Grigg, 1970; Grigg, Edwards \& Brown, 1971).

Phleomycin binds at the adenine-thymine rich regions in DNA, probably to the thymine bases (Falaschi \& Kornberg, I964; Pietsch \& Corbett, 1968), and distorts its secondary structure, inducing localized denaturation (Sleigh \& Grigg, 1974). These changes are thought to sensitize the DNA in vivo to enzymic attack, resulting in DNA breakdown and death (Grigg et al. 197I). Caffeine interacts with phleomycin-treated DNA to increase the frequency of locally denatured regions, and we have proposed that the ability of caffeine and other ligands such as coumarin and the thiopurines to bind preferentially to single-stranded DNA (Grigg et al. 197I) enables these compounds to enhance local denaturation around phleomycin-thymine complexes, resulting in the observed nuclease-induced DNA breakage, degradation and death.

In the structure-activity relationships of biologically active compounds, the relative lipotohydrophilicity indicated by the partition coefficient (p.c.) between octanol and water, may or may not be important (Albert, 1973). If the p.c. is a factor (as in antibacterial oxine derivatives), transport across a fatty cell membrane may be inferred; if not (as in the local anaesthetics), it may be assumed that no such process is involved. Preliminary observations (Brown, Jones, Angyal \& Grigg, I972) suggest that the lipophilicity conferred by substituents could be important to the potentiating activity of purines towards phleomycin.

We report the potentiating activities and p.c. values for 63 purines, and some tentative correlations between structure and biological activity. 
Table I. Phleomycin: amplifying activities, partition coefficients and sources of purines

\begin{tabular}{|c|c|c|c|c|}
\hline No. & Purine & $\begin{array}{l}\text { Adjusted } \\
\text { activity* }\end{array}$ & $\begin{array}{l}\text { Partition } \\
\text { coefficient } \dagger\end{array}$ & Source \\
\hline $\mathbf{I}$ & Unsubstituted & $2+$ & 0.4 & Albert \& Brown, 1954 \\
\hline 2 & 2-SMe & $20++$ & 10 & Albert \& Brown, 1954 \\
\hline 3 & $2,8-(\mathrm{SMe})_{2}$ & $70+++$ & 85 & Albert, 1966 \\
\hline 4 & 2-SMe-6-OH & $30++$ & - & $\begin{array}{l}\text { Elion, Lange \& Hitchings, } \\
1956\end{array}$ \\
\hline 5 & 2-SMe-8-OH & $20++$ & - & Noell \& Robins, 1959 \\
\hline 6 & 2-SEt & $70++$ & 36 & $\begin{array}{l}\text { Badger, Brown \& Lister, } \\
1973\end{array}$ \\
\hline 7 & 2-SEt-6-OH & $7++$ & - & Gouch \& Maguire, 1967 \\
\hline 8 & 6-SEt & $60++$ & 30 & $\begin{array}{l}\text { Elion, Goodman, Lange } \\
\text { \& Hitchings, I959 }\end{array}$ \\
\hline 9 & $\begin{array}{c}\text { 8-SEt } \\
\text { Monoalkyl }\end{array}$ & $70++$ & 13 & Badger et al. 1973 \\
\hline 10 & $6-\mathrm{Me}-2-\mathrm{SE}_{\mathrm{t}}$ & $280++++$ & 62 & $\begin{array}{l}\text { Badger, Brown \& Lister, } \\
1974\end{array}$ \\
\hline II & $6-\mathrm{Me}-2,8-(\mathrm{SMe})_{2}$ & $70+++$ & 153 & Brown et al. 1972 \\
\hline 12 & 6-Me-2-NMe ${ }_{2}$ & $220++++$ & - & Badger et al. 1974 \\
\hline 13 & 6-Et-2-SMe & $2+$ & 65 & Badger et al. 1974 \\
\hline 14 & 6-Et-2-NMe & $95+++$ & 96 & Badger et al. 1974 \\
\hline I 5 & 8-Me-2-SMe & $120++++$ & 17 & Brown et al. 1972 \\
\hline 16 & 8-Me-2-SEt & $450++++$ & 55 & Badger et al. 1973 \\
\hline 17 & 8-Et-2-SMe & $200++t+$ & 42 & Badger et al. 1973 \\
\hline 18 & 8-Et-2-SEt & $580+t+t$ & I5 I & Badger et al. 1973 \\
\hline 19 & 8-Ph-2-SEt & $2+$ & $<750$ & Badger et al. 1974 \\
\hline 20 & $8-\mathrm{CF}_{3}-2-\mathrm{OH}$ & $<\mathrm{I}+$ & 0.2 & Albert, 1966 \\
\hline $2 \mathrm{I}$ & 9-Me-2-SMe & $60++$ & IO & Brown \& Ford, 1969 \\
\hline 22 & 9-Me-2-SEt & IIO +++ & - & Badger et al. 1974 \\
\hline 23 & 9-Me-6-SMe & $30+t$ & 7 & Brown \& Ford, I969 \\
\hline 24 & 9-Me-8-SMe & $8+t$ & - & Brown \& Ford, 1969 \\
\hline 25 & 9-CH${ }_{2} \mathrm{Ph}-8-\mathrm{SMe}$ & $4++$ & 263 & $\begin{array}{l}\text { Brown, Ford \& Tratt, } \\
1967\end{array}$ \\
\hline \multicolumn{5}{|c|}{ Dialkyl } \\
\hline 26 & $2,9-\mathrm{Me}_{2}-6-\mathrm{SMe}$ & $25++$ & 25 & Brown et al. 1967 \\
\hline 27 & $2,9-\mathrm{Me}_{2}-8-\mathrm{SMe}$ & $310+++t$ & I0 & Brown et al. 1967 \\
\hline 28 & $6,7-\mathrm{Me}_{2}-2-\mathrm{SMe}$ & $500++t+$ & 4 & Brown et al. 1967 \\
\hline 29 & $6,8-\mathrm{Me}_{2}-2-\mathrm{SMe}$ & $80+t+$ & 一 & Brown et al. 1972 \\
\hline 30 & $6,8-\mathrm{Me}_{2}-2-\mathrm{NMe}_{2}\left(\mathrm{H}_{2} \mathrm{O}\right)$ & $230+++$ & $3 I$ & Badger et al. 1974 \\
\hline 31 & 6-Et-8-Me-2-SMe & $30++$ & 85 & Badger et al. 1974 \\
\hline 32 & 6-Et-8-Me-2-NMe ${ }_{2}$ & $60+t+$ & IIO & Badger et al. 1974 \\
\hline 33 & 8-Et-6-Me-2-SMe & $0++$ & 69 & Badger et al. 1973 \\
\hline 34 & 8-Et-6-Me-2-NMe ${ }_{2}$ & $45+++$ & 69 & Badger et al. 1974 \\
\hline 35 & $6,9-\mathrm{Me}_{2}-2 \mathrm{SMe}$ & $750++++$ & $2 \mathrm{I}$ & Brown et al. 1967 \\
\hline 36 & $6,9-\mathrm{Me}_{2}-2-\mathrm{SEt}$ & $80+t$ & 75 & Brown et al. 1972 \\
\hline 37 & $6,9-\mathrm{Me}_{2}-2-\mathrm{SH}$ & $35++$ & 7 & Brown et al. 1967 \\
\hline 38 & $6,9-\mathrm{Me}_{2}-2-\mathrm{SOMe}$ & $3+$ & $0 \cdot 1$ & Brown et al. 1972 \\
\hline 39 & $6.9-\mathrm{Me}_{2}-2-\mathrm{SO}_{2} \mathrm{Me}$ & $20++$ & $0 \cdot 1$ & Badger et al. 1974 \\
\hline 40 & $6,9-\mathrm{Me}_{2}-2-\mathrm{SCH}_{2} \mathrm{CO}_{2}^{-}$ & $<\mathrm{I}+$ & $<0.1$ & Grigg et al. I97I \\
\hline $4 \mathrm{I}$ & $6,9-\mathrm{Me}_{2}-2-\mathrm{SCH}_{2} \mathrm{CONH}_{2}$ & $510+t+t$ & 0.4 & Badger et al. 1974 \\
\hline 42 & $6,9-\mathrm{Me}_{2}-2-\mathrm{NMe}_{2}$ & $80++$ & 40 & Brown et al. 1972 \\
\hline 43 & $6,9-\mathrm{Me}_{2}-2-\mathrm{OMe}$ & $55++$ & 4 & Brown et al. 1972 \\
\hline 44 & 6,9-Me $\mathrm{Me}_{2}-2-\mathrm{SMe}-8-\mathrm{OH}$ & $2+$ & 30 & Brown et al. 1972 \\
\hline 45 & $6,9-\mathrm{Me}_{2}-2,8-(\mathrm{SMe})_{2}$ & $4++$ & 265 & Brown et al. 1972 \\
\hline 46 & 6-Et-9-Me-2-SMe & $155+++$ & 71 & Badger et al. 1974 \\
\hline 47 & 6-Et-9-Me-2-NHMe & $430++t+$ & - & Badger et al. 1974 \\
\hline 48 & 6-Et-9-Me-2-NMe $(\mathrm{HCl})$ & $330++++$ & 183 & Badger et al. 1974 \\
\hline 49 & 9-Et-6-Me-2-SMe & $40++$ & 68 & Badger et al. 1974 \\
\hline 50 & 9-Et-6-Me-2-NMe ${ }_{2}(\mathrm{HCl})$ & $25++$ & 142 & Badger et al. 1974 \\
\hline
\end{tabular}


Table I (cont.)

\begin{tabular}{|c|c|c|c|c|}
\hline No. & Purine & $\begin{array}{l}\text { Adjusted } \\
\text { activity* }\end{array}$ & $\begin{array}{c}\text { Partition } \\
\text { coefficient } \dagger\end{array}$ & Source \\
\hline $5 \mathrm{I}$ & Caffeine & $I I, 30++$ & 0.9 & - \\
\hline 52 & $2,6,8-\mathrm{Me}_{3}$ & $15++$ & 216 & Brown et al. 1972 \\
\hline 53 & $2,6,9-\mathrm{Me}_{3}$ & $<\mathrm{I}+$ & I & Brown et al. 1972 \\
\hline 54 & $6,8,9-\mathrm{Me}_{2}-2-\mathrm{SMe}$ & $30++$ & 32 & Brown et al. 1972 \\
\hline 55 & $6,8,9-\mathrm{Me}_{3}-2-\mathrm{NMe}_{2}$ & $20++$ & 46 & Brown et al. 1972 \\
\hline 56 & $6,8,9-\mathrm{Me}_{3}-2-\mathrm{OMe}$ & $80++$ & 5 & Brown et al. 1972 \\
\hline 57 & 6-Et-8,9-Me $\mathrm{Me}_{2}-2-\mathrm{SMe}$ & $8+$ & 80 & Badger et al. 1974 \\
\hline 58 & 6-Et-8,9-Me $-2-\mathrm{NHMe}$ & $430++++$ & 21 & Badger et al. 1974 \\
\hline 59 & 6-Et-8,9-Me $-\mathrm{Me}_{2}-2-\mathrm{NMe}_{2}\left(\mathrm{HCl} \cdot \mathrm{H}_{2} \mathrm{O}\right)$ & $350++++$ & - & Badger et al. 1974 \\
\hline 60 & 8-Et-6,9-Me ${ }_{2}-2-\mathrm{SMe}$ & I10 +++ & $6 I$ & Badger et al. 1974 \\
\hline $6 I$ & 8-Et-6,9-- $\mathrm{Me}_{2}-2-\mathrm{NMe}_{2}$ & $25++$ & 122 & Badger et al. 1974 \\
\hline 62 & 9-Et-6,8-Me $-2-\mathrm{SMe}$ & $90+++$ & 76 & Badger et al. 1974 \\
\hline 63 & $\begin{array}{l}\text { 9-Et-6,8- } \mathrm{Me}_{2}-2-\mathrm{NMe}_{2}\left(\mathrm{H}_{2} \mathrm{O}\right) \\
\text { Tetra-alkyl }\end{array}$ & $15++$ & 一 & Badger et al. 1974 \\
\hline 64 & $2,6,8,9-\mathrm{Me}_{4}$ & $6+$ & $2 \cdot 5$ & Brown et al. 1972 \\
\hline
\end{tabular}

* Values at $8 \mathrm{~mm}$ or $2 \mathrm{~mm}$ (italicized) concentration relative to $8 \mathrm{~mm}$-caffeine (30). Very highly active $(++++)=>$ Io times the activity of caffeine at the same concentration; highly active $(+++)=3$ to Io times caffeine; moderately active $(++)=0.3$ to 3.0 times caffeine; and slightly active $(+)=<0.3$ times caffeine

$\dagger n$-Octanol: water at $20^{\circ} \mathrm{C}$; aqueous buffer $\left(\mathrm{pH}_{7}\right)$ used for hydrochlorides.

\section{METHODS}

A culture of E. coli B was obtained from Ruth Hill. Phleomycin (batches A 933 I-648 and 6I6) was a gift of Bristol Laboratories Inc., Ithaca, New York, U.S.A. and the $n$-octanol and caffeine were commercial samples (Evans Medical Ltd and BDH, respectively). The sources of other purines are indicated in Table $\mathrm{I}$.

Biological activity. The E. coli $\mathrm{B}$ was grown overnight to stationary phase in a glucose+ salts medium (GT) (Grigg, 1969). Washed bacteria at a concentration of $10^{8} / \mathrm{ml}$ were suspended in fresh GT containing phleomycin ( $\mathrm{I}$ to $2 \mu \mathrm{g} / \mathrm{ml}$; dissolved immediately before the experiment) and incubated at $37^{\circ} \mathrm{C}$ for $30 \mathrm{~min}$. The bacteria were membrane-filtered $(0.45 \mu \mathrm{m}$ pore size) and resuspended in GT containing the purine under test ( 8 or $2 \mathrm{~mm}$, according to solubility). Samples were removed at the outset and at intervals during $120 \mathrm{~min}$ for estimation of the number of viable bacteria present (Grigg, 1970) using a commercial broth agar, Oxoid blood agar base, for counts. In each series of assays, 8 mM-caffeine was included as a standard (Grigg et al. 1971).

The amplifying activity of each purine is expressed in Table $I$ as an adjusted activity relative to the mean activity of $8 \mathrm{~mm}$-caffeine set at 30 , and hence independent of variations in conditions or in the amount or intrinsic activity of the phleomycin. Thus,

$$
A_{m}=N_{0} / N_{120} \text { and } A_{a d}=30 A_{m} / A_{\text {caf }},
$$

where $A_{m}$ is the measured activity of the purine, $A_{a d}$ is the adjusted activity, $N_{0}$ and $N_{120}$ are the numbers of viable bacteria initially and after $120 \mathrm{~min}$, respectively, and $A_{c a f}$ is the measured activity of $8 \mathrm{~mm}$-caffeine. Since the dose response curve is not linear over the range 2 to $8 \mathrm{~mm}$ for many compounds, activities for purines measured at $2 \mathrm{~mm}$ concentration (for solubility reasons) are not strictly comparable with those at $8 \mathrm{mM}$.

Partition coefficients. A solution of each purine in octanol-saturated water at $20{ }^{\circ} \mathrm{C}$ was prepared at a concentration measurable in a spectrophotometer. A sample was filtered using 
a syringe and Swinney adaptor containing a membrane filter (pore size 0.2 to $0.45 \mu \mathrm{m}$ ). The extinction $\left(E_{1}\right)$ of the clarified solution was measured at a suitable wavelength. A measured volume of the unfiltered solution was shaken for $10 \mathrm{~min}$ with a volume of octanol appropriate to the expected partition coefficient. After settling, the aqueous layer was withdrawn, filtered twice, and the extinction $\left(E_{2}\right)$ measured at the above wavelength. The whole procedure was repeated twice, with extended shaking times of 20 and $30 \mathrm{~min}$, respectively, to ensure that equilibrium had been attained. The p.c. was calculated for each sample from the equation:

$$
\text { p.c. }=\frac{V_{w}\left(\mathrm{I}-E_{2} / E_{1}\right)}{V_{0}\left(E_{2} / E_{1}\right)},
$$

where $V_{w}$ was the volume of aqueous solution and $V_{0}$ the volume of octanol. A spread of $10 \%$ in p.c. values was accepted. It proved essential to prewash filter membranes free of residual detergent which otherwise interfered with extinction measurements.

\section{RESULTS AND DISCUSSION}

It is evident from the results in Table $\mathrm{I}$ that a high level of potentiation is achieved in the monoalkylpurines with a 2-alkylthio or 2-dimethylamino substituent (nos. 10 to I2, I4 to I8, 22; exception: 13 ); in the dialkylpurines with a 2- or 8-methylthio group or a 2-mono- or 2-di-methylamino group (nos. 27 to $30,32,34,35,46$ to 48 ; exceptions: 3 I , 45, 50); and in a few trialkylpurines with similar substituents (nos. 54,58 to 60, 62: exceptions: $55,57,6 \mathrm{r}$, 63). The dialkylated purineamide (no. 4I) is also highly potentiating. Moderate potentiation, of the same order as caffeine, is shown by the unalkylated purines (nos. 2 to 9); by the 6-methylthiopurines (nos. 23, 26); and by the hydroxy-, benzyl-, mercapto-, methylsulphonyland methoxypurines (nos, 4, 5, 7, 25, 37, 39, 43, 56). Slight potentiation occurs from purine itself and its derivatives bearing trifluoromethyl, hydroxy, methylsulphinyl, carboxymethylthio, and (only) alkyl groups (nos. I, 20, 38, 40, 44, 53, 64; exception: 52). The connexion (Table I) between p.c. and potentiating activity is unclear at present: purines within the very highly active group $(++++)$, range in p.c. from 0.4 to 183 , and the spread within each of the other activity groups is similar. It follows that negotiation of a fatty barrier is not a critical factor in activity.

The use of a two-component antibiotic regime, namely phleomycin plus a purine - the two having an antibiotic effect equal to that generated by a substantially higher phleomycin level, increases the possibility of introducing target cell specificity. Phleomycin is taken up by most cellular species, whereas purines, though capable of permeating most cells, bind weakly and, given to an animal, are rapidly eliminated through the kidney to the bladder. They or their corresponding metabolites can be recovered quantitatively in the urine. In principle an appropriate regime of phleomycin plus purine may therefore be useful in selectively treating pathological conditions of the bladder. 6,9-Dimethyl-2-methylthiopurine (No. 35), although of low toxicity to mice (Angyal, unpublished data), is metabolically modified by oxidation to a sulphoxide (No. 38) (Brown et al. 1972) which is ineffective as a potentiator of phleomycin. The addition of a carbamoyl group to the methylthio group (no. 4I) prevents such enzymic modification (Brown \& Stephanson, 1974) without appreciably affecting its biological activity. Accordingly, its utility with phleomycin as a specific bladder antibiotic is being explored. 


\section{REFERENCES}

Albert, A. (1966). Purine studies. IV. A search for covalent hydration in 8-substituted purines. Journal of the Chemical Society B, 438-44I.

Albert, A. (1973). Selective Toxicity, 5th ed. London: Chapman \& Hall.

Albert, A. \& Brown, D. J. (I954). Purine studies. I. Stability to acid and alkali, Solubility. Ionization. Comparison with pteridines. Journal of the Chemical Society, 2060-207I.

Badger, R. J., Brown, D. J. \& Lister, J. H. (I 973). Purine studies. VIII. Formation of alkylthiopurines from 4,5-diaminopyrimidine- or purine-thiones by means of orthoester-anhydride mixtures. Journal of the Chemical Society, Perkin Transactions I, 1906-1909.

Badger, R. J., Brown, D. J. \& Lister, J. H. (1974). Purine studies. X. Further synthetic approaches to purines for the amplification of phleomycin activity against E. coli. Journal of the Chemical Society, Perkin Transactions $\mathrm{x}, \mathrm{I} 52-\mathrm{I} 58$.

Bradner, W. T. \& Pindell, M. H. (1962). Antitumor properties of phleomycin. Nature, London 196, 682683.

Brown, D. J. \& Ford, P. W. (I969). Purine studies. VI. Formation, hydrolysis, and aminolysis of some purine sulphoxides and sulphones. Journal of the Chemical Society C, 2620-2624.

Brown, D. J., Ford, P. W. \& TratT, K. H. (1967). Purine studies. V. Formation and aminolysis of some methylthiopurines. Journal of the Chemical Society C, I445-I449.

Brown, D. J., Jones, R. L., Angyal, A. M. \& Grigg, G. W. (1972). Purine studies. VII. The synthesis of purines as amplifiers of phleomycin against E. coli. Journal of the Chemical Society, Perkin Transactions I, I8I9-I825.

Brown, D. J. \& Stephanson, L. G. (1974). Purine studies. XIII. The metabolism of 2,9-dimethyl-8methylthiopurine and 2-carbamoylmethylthio-6,9-dimethylpurine in mice. Australian Journal of Chemistry 27. (In the Press.)

Elion, G. B., Goodman, I., Lange, W. H. \& Hitchings, G. H. (I959). Condensed pyrimidine systems. XX. Purines related to 6-mercaptopurine and thioguanine. Journal of the American Chemical Society 8I, I898-1902.

Elion, G. B., Lange, W. H. \& Hitchings, G. H. (1956). Studies on condensed pyrimidine systems. XIII. Some amino-substituted derivatives of guanine and 6-thioguanine. Journal of the American Chemical Society 78, 21 7-220.

FAlASChi, A. \& Kornberg, A. (1964). Phleomycin, an inhibitor of DNA polymerase. Federation Proceedings 23, 940-945.

Gouch, G. \& Maguire, M. H. (1967). Some biologically active $N^{6}$-methylated adenosine analogues. Journal of Medicinal Chemistry ro, 475-478.

GrIGG, G. W. (1969). Induction of DNA breakdown and death in Escherichia coli by phleomycin. Its association with dark-repair processes. Molecular and General Genetics ro4, I-I I.

GrIGG, G. W. (1970). Amplification of phleomycin-induced death and DNA breakdown by caffeine in Escherichia coli. Molecular and General Genetics 107, 162-172.

GrigG, G. W., Edwards, M. J. \& Brown, D. J. (197I). Effects of coumarin, thiopurines, and pyronin-Y on amplification of phleomycin-induced death and deoxyribonucleic acid breakdown in Escherichia coli. Journal of Bacteriology 107, 599-609.

IWATA, A. \& CONSIGLI, R. A. (1971). Effect of phleomycin on polyoma virus synthesis in mouse embryo cells. Journal of Virology 7, 29-40.

Kihlman, B. A., Odmark, G. \& Hartley, B. (I967). Effects of phleomycin on chromosome structure and nucleic acid synthesis in Vicia faba. Mutation Research 4, 783-790.

Maeda, K., KosaKa, H., Yagishita, K. \& Umezawa, H. (1956). A new antibiotic, phleomycin. Journal of Antibiotics A 9, 82-85.

NoELL, C. W. \& Robins, R. K. (1959). Potential purine antagonists. XVII. Synthesis of some 2-methyl- and 2-methylthio-6,8-disubstituted purines. Journal of Organic Chemistry 24, 320-323.

Pietsch, P. \& CoRbetT, C. (1968). Competitive effects of phleomycin and mercuric chloride in vivo. Nature, London 219, 933-934.

Reiter, H., Milewskiy, M. \& Kelley, P. (1972). Mode of action of phleomycin on Bacillus subtilis. Journal of Bacteriology III, 586-592.

Sleigh, M. J. \& GRIGG, G. W. (1974). Induction of local denaturation in DNA in vitro by phleomycin and caffeine. FEBS Letters 39, 35-38. 
Smale, B. C., Montgillion, M. D. \& Pridham, T. G. (196i). Phleomycin, an antibiotic markedly effective for control of bean rust. Plant Diseases Reporter 45, $244-247$.

Takita, T., Muraoka, Y., Yoshioka, T., FujI, A., Maeda, K. \& Umezawa, H. (1972). The chemistry of bleomycin. IX. The structure of bleomycin and phleomycin. Journal of Antibiotics A25, 755-758.

Tanaka, N., Yamaguchi, H. \& Umezawa, H. (1963). Mechanism of action of phleomycin. I. Selective inhibition of deoxyribonucleic acid synthesis in Escherichia coli and in HeLa cells. Journal of Antibiotics Ar6, 86-9r. 